Przegląd Badań Edukacyjnych Educational Studies Review

ISSN 1895-4308

nr 24 (1/2017), s. 277-312

METODY ZBIERANIA

I ANALIZY DANYCH

W BADANIACH EDUKACYJNYCH

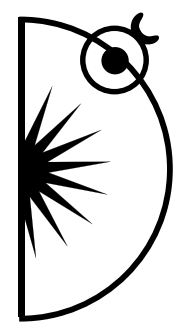

Jeffry A. Simpson

Texas A\&M University, e-mail: simps108@umn.edu

Steven W. Gangestad

University of New Mexico, e-mail: sgangest@unm.edu

Emilia Aksamit (tłumaczenie)

Uniwersytet Mikołaja Kopernika, e-mail: e.m.aksamit@tlen.pl

\title{
Indywidualne różnice w socjoseksualności: dowody na trafność konwergencyjną i dyskryminacyjną
}

DOI: http://dx.doi.org/10.12775/PBE.2017.016

\section{Individual Differences in Sociosexuality: Evidence for Convergent and Discriminant Validity}

\begin{abstract}
Individual differences in willingness to engage in uncommitted sexual relations were investigated in 6 studies. In Study I, a 5-item Sociosexual Orientation Inventory (SOl) was developed. Studies 2, 3, and 4 provided convergent validity evidence for the SOI, revealing that persons who have an unrestricted sociosexual orientation tend to (a) engage in sex at an earlier point in their relationships, (b) engage in sex with more than 1 partner at a time, and (c) be involved in relationships characterized by less investment, commitment, love, and dependency. Study 5 provided discriminant validity for the SOI, revealing that it does not covary appreciably with a good marker of sex drive. Study 6 demonstrated that the SOI correlates negligibly with measures of sexual satisfaction, anxiety, and guilt. The possible stability of, origins of, and motivational bases underlying individual differences in sociosexuality are discussed. ${ }^{1}$
\end{abstract}

${ }^{1}$ Badania wspierał Narodowy Instytut Zdrowia Psychicznego w ramach Grantu MH45081 otrzymanego przez Jeffreya A. Simpsona. Podziękowania za pomoc w realizacji fazy empirycznej 
Key words: Sociosexual orientation, Sociosexual Orientation Inventory (SOI), sociosexual behaviore, sociosexual attitude.

Ponad 50 lat temu Alfred Kinsey i jego współpracownicy rozpoczęli najbardziej ambitne, wszechstronne i dogłębne studium zachowań seksualnych i praktyk ludzkich. Chociaż Kinseyowi zależało przede wszystkim na opisaniu norm populacyjnych (np. średnich wartości dla zachowań seksualnych), jedną z najbardziej uderzających cech jego danych było znaczne zróżnicowanie w szerokim zakresie tego, co określił jako postawy i zachowania socjoseksualne (Kinsey, Pomeroy, Martin, 1948; Kinsey, Pomeroy, Martin, Gebhard, 1953). Rzeczywiście, jak pokazują nowsze badania, ludzie wykazują znaczną zmienność w kilku socjoseksualnych aspektach z tendencją do współzmieniania się. Należy do nich częstotliwość faktycznych i preferowanych kontaktów seksualnych, rzeczywista i preferowana liczba partnerów, liczba różnych partnerów seksualnych planowanych w przyszłości, postawa wobec niezobowiązujących stosunków seksualnych, łatwość podejmowania niezaangażowanych relacji seksualnych oraz częstotliwość, z jaką seksualne fantazje na temat partnerów innych niż obecni dominują w myślach (patrz: Eysenck, 1976; Hunt, 1974; Snyder, Simpson, Gangestad, 1986).

Biorąc pod uwagę, że wiele $\mathrm{z}$ tych zachowań i postaw socjoseksualnych silnie współzmienia się, Synder i in. (1986), Gangestad i Simpson (1990) sugerują, że mogą one mieścić się we wspólnym wymiarze indywidualnych różnic odzwierciedlających orientację socjoseksualna lub socjoseksualność. Osoby z jednego końca tego wymiaru, które posiadają restrykcyjną orientację socjoseksualna, zazwyczaj kładą nacisk na oddanie i bliskość z partnerem w relacji romantycznej przed angażowaniem się w seks. Ponadto osoby te twierdzą, że potrzebują poczucia bliskości, aby seks był dla nich komfortowy, że odbyły kilka stosunków seksualnych w ciągu ostatniego roku i rzadko, jeśli w ogóle, uprawiały przygodny seks. Natomiast osoby znajdujące się na drugim końcu tego wymiaru, które przejawiają nierestrykcyjna orientację socjoseksualna, czują się komfortowo, podejmując relacje seksualne bez zobowiązań czy bliskości. De-

badań kierujemy w stronę następujących osób: Lany Aaron, Sheri Baker, Holly Bogart, Debbie Grudrein, Mindy Hall, Lisy Hutchins, Margaret Lermy, Jima Lyona, Paula Nicolaia, Karen Owens, Faith Short, Sary Sloan, Nicole Streetman i Richarda Williamsa. Korespondencję dotyczącą tego artykułu należy kierować pod adres: Jeffry A. Simpson, Department of Psychology, Texas A\&M University, College Station, Texas 77843; lub Steven W. Gangestad, Department of Psychology, University of New Mexico, Albuquerque, New Mexico 87131. 
klarują one na przykład, że mogą cieszyć się seksem bez zobowiązań, że miały kilku różnych partnerów seksualnych w ciągu ostatniego roku oraz że przeżyły kilka jednorazowych, niezobowiązujących kontaktów seksualnych.

Niektóre z rozbieżności w zachowaniach i postawach socjoseksualnych mogą mieć swoje podłoże w różnicach płciowych. Mężczyźni, w odróżnieniu od kobiet, przejawiają postawy bardziej liberalne i wykazują więcej nieograniczonych zachowań w odniesieniu do podejmowania niezobowiązujących stosunków seksualnych (np. Buss, Barnes, 1986; Eysenck, 1976; Griffit, Hatfield, 1985; Hendrick, Hendrick, Slapion-Foote, Foote, 1985). Niemniej jednak praktycznie wszystkie wskaźniki w obrębie socjoseksualności charakterystyczne dla każdej z płci znacznie przekraczają to, co istnieje między mężczyznami i kobietami (np. Eysenck, 1976; Hendrick i in., 1985; Hunt, 1974; Kinsey i in., 1948;.

Kinsey i in., 1953; Snyder i in., 1986). Na przykład Hendrick (1985) wskazał na znaczne różnice $\mathrm{w}$ stosunku do rozwiązłości seksualnej między studentami a studentkami, jednakże rozbieżność w „ocenie lekkich obyczajów” w obrębie płci była ponaddwukrotnie większa niż średnia dla wszystkich badanych.

\section{Dotychczasowe badania nad socjoseksualnością}

Wskazać można kilka projektów badawczych skupiających się na ocenie zróżnicowania ludzi ze względu na płeć w obrębie socjoseksualności. Postawy wobec różnych tematów związanych z płcią (np. homoseksualizm, pornografia, prostytucja, aborcja, obyczaje seksualne) są regularnie kształtowane przez indywidualny poziom erotofobii danej osoby (Byrne, Sheffield, 1965; Fisher, 1984; Gerrard, 1980; Gerrard, Gibbons, 1982), poczucie winy związanej z seksem (Mosher, 1979; O'Grady, Janda, Gillen, 1979), oraz społeczny/seksualny lęk (Leary, Dobbins, 1983). W szczególności osoby, które mają bardziej konserwatywne poglądy w odniesieniu do tych tematów wykazują zachowania związane z erotofobią i przejawiają wyższy poziom poczucia winy seksualnej i lęku społecznego/seksualnego.

Również kilka głównych cech osobowości i obszary indywidualnych różnic współzmieniają się z różnymi zachowaniami i postawami socjoseksualnymi. Na przykład osoby, które uzyskały wysokie co do średnich wyniki w obszarze ekstrawersji (Eysenck, 1974, 1976), odhamowania (Zuckerman, Bone, Neary, Mangelsdorff, Brustman, 1972; Zuckerman, Tushup, Finner, 1976), i samokontroli (Snyder i in., 1986), prezentują tendencję do bardziej liberalnych postaw wobec nieobowiązującego seksu i są częściej skłonne do podejmowania różnorodnych form zachowań seksualnych w porównaniu z osobami, których 
wyniki w w/w obszarach są niskie. Co więcej, osoby liberalne seksualnie są mniej religijne (Byrne, 1983; Reiss, 1967; Zuckerman i in., 1976), mniej społecznie i politycznie konserwatywne (Curran, Neff, Lippold, 1973; D’Augelli, Cross, 1975; Eysenck, 1976; Griffit, 1973), i lepiej wykształcone (Alston, Tucker,1973; Hunt, 1974) w stosunku do osób mniej liberalnych.

Pomimo faktu, że większość dotychczasowych badań ma stosunkowo ateoretyczny charakter (Clayton, Bokemeier, 1980), kilku badaczy próbowało dostarczyć danych teoretycznych dla wyjaśnienia zmienności socjoseksualności w kontekście płci. Za ogólnie przyjętą uznano perspektywę popędu płciowego (Kelley, 1978). Różnice indywidualne w postawach i zachowaniach socjoseksualnych są przypuszczalnie wynikiem różnic indywidualnych w poziomie ogólnego zainteresowania seksem, przy czym osoby, które prezentują liberalne postawy i zachowania socjoseksualne, mają wyższy poziom popędu seksualnego niż te mniej liberalne (np. Eysenck, 1976; Kelley J., 1978; Libby, Gray, White, 1978; Reiss, 1982).

\section{Wady wcześniejszych badań nad socjoseksualnością}

Chociaż znaczna część badań skupiała się na różnych aspektach postaw i zachowań socjoseksualnych, i tak wskazać można na kilka niedociągnięć. Po pierwsze, wcześniejsze badania zazwyczaj nie identyfikowały postaw i zachowań socjoseksualnych w kontekście trwających romantycznych relacji (Peplau, Rubin, Hill, 1977). Bardziej niż na opisie minionych doświadczeń seksualnych w stosunku do obecnych relacji romantycznych ludzi skupiono się na prześledzeniu przebiegu ogólnych doświadczeń seksualnych, pomijając ich znaczenie dla bieżących związków badanych ${ }^{2}$.

Po drugie, wiele narzędzi pomiarowych, stosowanych w poprzednich badaniach nad socjoseksualnością, nie zostało zweryfikowanych. Opracowano

2 Przeprowadzono badania w których określono skutki różnic indywidualnych w postawach i zachowaniach socjoseksualnych w obrębie relacji. Prawie wszystkie z nich, skupiały się na indywidualnych różnicach w gotowości do podejmowania przedmałżeńskich stosunków seksualnych (np. D’Augelli, D’Augelli,1977; Ehrmann, 1959; Jessor, Costa, Jessor, Donovan, 1983; Jurich, Jurich, 1974; J. Kelley, 1978; Landis, Landis, 1958; Reiss, 1967), a nie na indywidualnych różnicach w gotowosci do uprawiania seksu bez poczucia miłości, zaangażowania i emocjonalnej bliskości. Chociaż przedmałżeńskie obyczaje seksualne odzwierciedlają istotne zachowania, to znacznie różnią się od permisywizmu seksualnego w przypadku braku zaangażowania i silnej uczuciowej więzi z partnerem seksualnym (por. Eysenck, 1976; Peplau, Rubin, Hill, 1977; Reiss, 1967). Ponadto, w celu zbadania zdefiniowanych uprzednio obszarów socjoseksualności, koncepcja seksualnego permisywizmu przedmałżeńskiego jest mniej przydatna. 
kilka inwentarzy do oceny postaw i różnych form zachowań seksualnych (np. Eysenck, 1976; Hendrick i in., 1985), nie jest jednak jasne, czy i w jaki sposób narzędzia te odnoszą się do rzeczywistych zachowań seksualnych. Zaznaczyć należy, że czym innym jest deklarowanie gotowości do podejmowania relacji seksualnych bez emocjonalnej bliskości, a czym innym rzeczywiste realizowanie takich działań (Griffit, Hatfield, 1985). Biorąc pod uwagę często wątpliwy związek między postawami i zachowaniami (Wicker, 1969), w połączeniu z faktem, że na ilość i charakter indywidualnych doświadczeń człowieka może wpływać kilka innych czynników niezwiązanych z postawami wobec niezobowiązującego seksu (np. atrakcyjność; Berscheid, Walster, 1978), wszelkie działania zmierzające do pełnej oceny orientacji socjoseksualnej powinny zawierać zarówno elementy postaw, jak i zachowań. Co więcej, różnice indywidualne $\mathrm{w}$ orientacji socjoseksualnej powinny być mierzone na obu poziomach. Jeden taki przypadek został opisany w literaturze (Mahoney, 1980), jednak użyte do badania narzędzie nie było wystandaryzowane. Na podstawie dotychczasowej tylko wiedzy można stwierdzić, że nie istnieje narzędzie pozwalające na rzetelny pomiar indywidualnych różnic w skłonności do podejmowania niezobowiązujących relacji seksualnych.

Po trzecie, choć związek popędu płciowego z permisywizmem seksualnym nadal niejawnie przewodzi badaniom, postulaty teoretyczne tej perspektywy pozostają niesprawdzone. W szczególności perspektywa popędu płciowego sugeruje, że dwa wskaźniki, czyli ogólne zainteresowanie seksem bez zaangażowania emocjonalnego i częstotliwość niezobowiązujących relacji, znacznie współzmieniają się, biorąc pod uwagę, że każdy powinien wskazywać na wyższe ogólne zainteresowanie seksem (por. Kelley J., 1978). Stwierdzenie to nigdy nie zostało przetestowane, a ostatnie badania dowodzą, że nie może być prawdziwe. Snyder (1986) zidentyfikował dwa niezależne czynniki leżące u podstaw zachowań i postaw socjoseksualnych. Pierwszy z nich odzwierciedla indywidualne różnice w skłonności do podejmowania niezobowiązujących kontaktów seksualnych; drugi - różnice w ilości i częstotliwości doświadczeń lub aktywności seksualnych. Podobnie Hendricks (1985), który wskazał, że czynniki decydujące o zainteresowaniu częstym odbywaniem stosunków seksualnych nie mają wpływu na wskaźnik dotyczący swobody seksualnej. Ustalenia te, jeżeli zweryfikować dane niesamoopisowe, nie byłyby możliwe $\mathrm{w}$ oparciu na teorii popędu płciowego, jednak są zgodne z innymi perspektywami.

Z punktu widzenia ewolucji czynniki takie jak czas, stopień zaangażowania i zażyłość emocjonalna, wymagane przez daną osobę przed stosunkiem sek- 
sualnym, zostały poddane innym naciskom selekcji niż te, które wpłynęły na częstotliwość seksu w ramach trwających, długotrwałych relacji (Mellen, 1981; Symons, 1979). Można stwierdzić, że niezobowiązujący seks i częsty seks odzwierciedlają bardzo różne poziomy zaangażowania w związek. Podczas gdy uprawianie seksu bez zobowiązań zakłada brak inwestycji w relacje (Symons, 1979), częstotliwość kontaktów seksualnych w bliskiej, silnej relacji odzwierciedla zaangażowanie i wzmaga inwestowanie w związek (Mellen, 1981).

Biorąc pod uwagę opisane nieprawidłowości, naszymi badaniami kierowały trzy cele:

1. Określenie, czy ogólny, a zarazem podstawowy wymiar postaw i zachowań socjoseskualnych może być zidentyfikowany i poddany rzetelnej ocenie. W badaniu 1 zidentyfikowaliśmy (poprzez analizę czynnikową) pięć wskaźników, które odzwierciedlają stopień, w jakim osoby badane przejawiały restrykcyjną $\mathrm{w}$ porównaniu z nierestrykcyjną orientację w stosunku do uprawiania seksu bez zobowiązań. Te pięć wskaźników zoperacjonalizowanych zostało w pozycjach Inwentarza Orientacji Socjoseksualnej (SOI).

2. Ocena trafności konwergencyjnej dla wyników z testów samoopisowych dotyczących zachowań i postaw opisanych w SOI, w odniesieniu do kryteriów zewnętrznych (niezależna ocena środowiskowa). Badania 2, 3 i 4 zostały zaprojektowane w celu zapewnienia dowodów na trafność teoretyczną. Jeśli osoby nierestrykcyjne są bardziej skłonne do podejmowania niezobowiązujących kontaktów seksualnych niż te, których orientacja jest restrykcyjna, to wymagać powinny mniejszego nakładu czasu, braku wyłączności seksualnej, słabszego zaangażowania, poświęcenia oraz przywiązania emocjonalnego do partnerów przed rozpoczęciem współżycia seksualnego. W związku z tym trzy następujące założenia dotyczące walidacji powinny się potwierdzić: (a) osoby o orientacji nierestrykcyjnej powinny uprawiać seks we wcześniejszym etapie związku niż osoby przejawiające orientację restrykcyjną (badanie 2); (b) osoby restrykcyjne, w stosunku do nierestrykcyjnych, powinny rzadziej uprawiać seks z więcej niż jednym partnerem w tym samym czasie (badanie 3); oraz (c) relacje osób nierestrykcyjnych powinny charakteryzować się mniejszym poświęceniem, niższą uczuciowością, mniejszym zaangażowaniem i poczuciem przynależności, w porównaniu do osób restrykcyjnych (badanie 4).

3. Weryfikacja głównych założeń teoretycznych leżących u podstaw większości poprzednich modeli permisywizmu seksualnego. W tym, 
czy ustalona miara dla indywidualnych różnic w gotowości do podjęcia niezobowiązujących stosunków seksualnych jest inna niż dla indywidualnych różnic $\mathrm{w}$ popędzie płciowym oraz w ogólnym zainteresowaniu seksem. Na podstawie najnowszych teorii i badań postawiono hipotezę, że socjoseksualność nie powinna silnie korelować z częstotliwościa aktywności seksualnych. Biorąc pod uwagę, że trafność teoretyczna pociąga za sobą rozwój teorii i badań (Cronbach, Meehl, 1955), badanie 5 zaprojektowaliśmy w celu zweryfikowania tej hipotezy i obliczenia mocy dyskryminacyjnej dla pozycji SOI. Badanie 6 miało na celu określić związki empiryczne SOI z innymi istniejącymi narzędziami do pomiaru seksualności.

\section{Badanie 1}

W badaniu 1 staraliśmy się ustalić, czy możliwy jest pomiar wymiaru odzwierciedlającego indywidualne różnice $\mathrm{w}$ gotowości do podjęcia niezobowiązujących kontaktów seksualnych. Zgodnie z zaleceniami przedstawianymi przez Loevinger (1957), nasz pierwotny kwestionariusz zawierał pozycje zarówno dla postaw, jak i zachowań, które powinny być związane z gotowością do podjęcia niezobowiązujących relacji seksualnych (postawa do uprawiania niezobowiązującego seksu, jednorazowe stosunki seksualne itp.), a także pozycje, które niekoniecznie powinny zaliczać się do tego konstruktu (np. częstotliwość seksu w ciągu ostatniego miesiąca).

\section{Metoda}

\section{Uczestnicy}

W badaniu w ramach kursu Wprowadzenie do psychologii na Texas A\&M University wzięło udział 406 osób (204 kobiety i 202 mężczyzn).

\section{Procedura}

Uczestnicy w grupach od 20 do 50 osób zgłaszali się do sali doświadczalnej. Osoby badane zostały poinformowane, że będą wypełniać anonimowy kwestionariusz, dotyczący aspektów ich dotychczasowego społecznego i seksualnego życia. W celu zapewnienia anonimowości uczestnicy badania zostali (a) rozsadzeni co drugie krzesło, (b) poproszeni o niepodpisywanie kartek, (c) poinformowani o możliwości umieszczenia wypełnionego kwestionariusza w nieoznakowanych kopertach, oraz (d) poproszeni o pozostawienie kart w pudełku 
zbiorczym dla wszystkich kwestionariuszy. Po zakończeniu badania uczestnikom podziękowano i dano możliwość zadawania pytań i zgłaszania uwag.

Oprócz podania informacji dotyczących płci, wieku i obecnego statusu związku, uczestnicy odpowiedzieli na kilka pytań, które oceniały różne aspekty ich jawnych i ukrytych zachowań i postaw socjoseksualnych.

\section{Pomiar}

Jawne pozycje behawioralne: sześć poniższych pytań wykorzystaliśmy do oceny różnych aspektów jawnych zachowań seksualnych:

1. Częstotliwość odbywania stosunków seksualnych w ostatnim miesiącu: "Ile razy uprawiałeś seks w ciągu ostatniego miesiąca?"

2. Dotychczasowa liczba partnerów seksualnych: „Z iloma partnerami uprawiałeś seks w swoim życiu?"

3. Liczba partnerów w ostatnim roku: „Z iloma partnerami uprawiałeś seksu w ciągu ostatniego roku?"

4. Liczba pożadanych partnerów: „Jeśli nic Cię nie hamuje (np. nie istnieje zagrożenie zarażenia się AIDS, chorobami wenerycznymi, opryszczką, nie boisz się niechcianej ciąży, twój partner/partnerzy nie widzą przeciwwskazań itd.), to z iloma osobami (które obecnie znasz) chciałbyś uprawiać seks?"

5. Przewidywana liczba partnerów: „Z iloma partnerami przewidujesz uprawiać seks w ciągu najbliższych 5 lat?"

6. Liczba jednorazowych stosunków seksualnych: „Z iloma partnerami uprawiałeś seks tylko jeden raz?"

Ukryte pozycje behawioralne: dwa następujące pytania pozwoliły nam ocenić ukryte aspekty indywidualnych zachowań seksualnych:

1. Częstotliwość myśli seksualnych: „Jak często myślisz o seksie?” (ocenione na skali 9-stopniowej: 1 = praktycznie nigdy, 9 = prawie caty czas)

2. Częstotliwość fantazji seksualnych: „Jak często fantazjujesz (fantazjowałeś) o seksie z kimś innym niż z bieżącym (ostatnim) partnerem?" (ocenione na skali 8-stopniowej: $1=$ nigdy, $8=$ co najmniej raz dziennie).

Pozycje dotyczące postaw: Trzy poniższe pytania pozwoliły nam ocenić indywidualne postawy wobec podejmowania przypadkowych i niezobowiązujących kontaktów seksualnych: 
1. „Seks bez miłości jest OK.”

2. „Potrafię sobie wyobrazić siebie w komfortowej i satysfakcjonującej relacji seksualnej z przypadkowymi partnerami."

3. „Musiałbym być blisko z kimś (zarówno emocjonalnie, jak i psychicznie), zanim mógłbym czuć się komfortowo i być w pełni usatysfakcjonowanym seksem z nim/nią."

Ostatnia pozycja została odwrócona. Wszystkie trzy pytania dawały możliwość udzielenia odpowiedzi na skali 9-stopniowej, gdzie $1=z$ decydowanie się nie zgadzam, 9 = zdecydowanie się zgadzam. Ponieważ te trzy pytania były silnie skorelowane (parami korelacje wahały się od .60 do $.67 \mathrm{rs}$ ), możemy połączyć je w celu utworzenia jednolitego, bardziej niezawodnego wskaźnika postaw wobec przygodnego, niezobowiązującego seksu (alfa Cronbacha $=.83$ ).

\section{Wyniki i dyskusja}

Korelacja pomiędzy pozycjami testu przedstawiona została osobno dla kobiet i mężczyzn w tabeli 1. Aby określić, czy istnieje wymiar odzwierciedlający indywidualne różnice w gotowości do podejmowana niezobowiązujących relacji seksualnych, przedstawiliśmy odpowiedzi dla pozycji kwestionariusza na głównej osi analizy czynnikowej (SPSSX PA2) ${ }^{3}$. Na podstawie wartości własnej w teście osypiska (Cattella, 1966) i interpretacyjności faktora, jeden z głównych stałych czynników o wyniku $39,2 \%$ został wyodrębniony z całkowitej wariancji. Czynnik ten wydaje się odzwierciedlać zmienność gotowości do podejmowania niezobowiązujących relacji seksualnych. Dane dotyczące ładunków czynnikowych przedstawia tabela 2.

Pozycje kwestionariusza, które osiągały najwyższe wartości statystyczne, odzwierciedlały indywidualne różnice w gotowości do podejmowania niezobowiązujących relacji seksualnych z wieloma partnerami (np. liczba partnerów seksualnych w przeszłości; liczba jednorazowych kontaktów seksualnych; stosunek do podejmowania przypadkowych, niezobowiązujących relacji seksualnych). Przeciwnie pozycja, która nie osiągała wysokich wartości i wskazywała na różnice w aktywności seksualnej (częstotliwość podejmowania stosunków

${ }^{3}$ Główne czynniki analizy, prowadzone na mniejszych grupach kobiet i mężczyzn, również ujawniły jeden główny wskaźnik o podobnym wyniku. Rzeczywiście, pięć pozycji, które ostatecznie wchodziły w skład naszego kwestionariusza, miało najwyższe wartości w obrębie grup zarówno kobiet, jak i mężczyzn. Dlatego zaprezentowaliśmy wyniki w odniesieniu do całej badanej próby. 
w przeszłości). Pozycje pośrednio mierzące gotowość do podejmowania niezobowiązujących relacji seksualnych osiągały wartości umiarkowane (np. częstotliwości myśli seksualnych, liczba pożądanych partnerów).

Przed przystąpieniem do konstruowania kwestionariusza wyznaczyliśmy dwa kryteria wyboru pozycji kwestionariusza. Po pierwsze, wszystkie potencjalne pozycje musiały uzyskiwać wysokie wyniki dla stałego czynnika (.50 lub więcej). Po drugie, żadna z załączonych pozycji nie może współzmieniać się znacznie (i tym samym potencjalnie być mylona) z wiekiem badanych. Sześć pozycji przedstawionych $\mathrm{w}$ tabeli 2 spełnia pierwsze kryterium. Pięć z nich (z wyjątkiem liczby partnerów życiowych) spełnia również drugie kryterium ${ }^{4}$. W związku z tym ostateczna wersja inwentarza składa się z pięciu pozycji pozwalających zmierzyć: liczbę partnerów w minionym roku, przewidywaną liczbę partnerów, liczbę jednorazowych stosunków seksualnych, częstotliwość fantazji seksualnych oraz postawy wobec swobodnej, niezaangażowanej relacji seksualnej.

Ponieważ wybrane przez nas pozycje kwestionariusza posiadają różne skale odpowiedzi, najpierw wystandaryzowaliśmy każdą pozycję na mniejszych próbach kobiet i mężczyzn, przekształcając uzyskane przez nich wyniki, co pozwoliło na ustalenie wspólnej miary dla w/w pozycji. Następnie zebraliśmy już przekształcone pozycje w celu opracowania wyniku ogólnego odzwierciedlającego różnice indywidualne (alfa Cronbacha $=.73$; załącznik A).

Tabela 1. Współczynnik korelacji Pearsona pomiędzy kryteriami oceniającymi socjoseksualność: Badanie 1.

\begin{tabular}{|l|c|c|c|c|c|c|c|c|c|}
\hline \multicolumn{1}{|c|}{ Zmienna } & $\mathbf{1}$ & $\mathbf{2}$ & $\mathbf{3}$ & $\mathbf{4}$ & $\mathbf{5}$ & $\mathbf{6}$ & $\mathbf{7}$ & $\mathbf{8}$ & $\mathbf{9}$ \\
\hline $\begin{array}{l}\text { 1. Częstotliwość uprawiania seksu w ostatnim } \\
\text { miesiącu }\end{array}$ & ---- & .33 & .30 & -.08 & .05 & .18 & .07 & -.05 & .12 \\
\hline 2. Liczba partnerów życiowych & .24 & ----- & .69 & .19 & .31 & .64 & .12 & .15 & .47 \\
\hline 3. Liczba partnerów w ubiegłym roku & .24 & .80 & ---- & .15 & .43 & .39 & .15 & .25 & .43 \\
\hline 4. Liczba pożądanych partnerów & -.02 & .24 & .30 & ---- & .26 & .12 & .23 & .25 & .34 \\
\hline
\end{tabular}

${ }^{4}$ Ponieważ pozycja mierząca liczbę parterów w ubiegłym roku była silnie skorelowana z pozycjami badającymi liczbę partnerów życiowych $(\mathrm{r}=.73)$, pierwsza nie współzmieniała się $\mathrm{z}$ wiekiem respondentów $(\mathrm{r}=.09)$, jednak druga już tak $(\mathrm{r}=.26)$, toteż pozycja wskazująca liczbę partnerów życiowych nie została włączona do SOI. W przypadku osób starszych bardziej prawdopodobne jest, że miały one większą liczbę partnerów seksualnych niż osoby młodsze, niezależnie od orientacji socjoseksualnej. W związku z tym uznaliśmy, że pozycja dotycząca liczby partnerów w ostatnim roku posłuży jako dokładniejszy wskaźnik socjoseksualności. 
Jeffry A. Simpson, Steven W. Gangestad, Emilia Aksamit Indywidualne różnice...

Tabela 1. Współczynnik korelacji Pearsona pomiędzy kryteriami oceniającymi socjoseksualność: Badanie 1.

\begin{tabular}{|l|c|c|c|c|c|c|c|c|c|}
\hline \multicolumn{1}{|c|}{ Zmienna } & $\mathbf{1}$ & $\mathbf{2}$ & $\mathbf{3}$ & $\mathbf{4}$ & $\mathbf{5}$ & $\mathbf{6}$ & $\mathbf{7}$ & $\mathbf{8}$ & $\mathbf{9}$ \\
\hline 5. Przewidywana liczba partnerów & -.01 & .32 & .42 & .30 & ---- & .22 & .09 & .21 & .39 \\
\hline 6. Liczba stosunków seksualnych na jedną noc & .20 & .72 & .71 & .23 & .27 & ---- & .19 & .09 & .44 \\
\hline 7. Częstotliwość występowania myśli seksualnych & .18 & .14 & .25 & .21 & .22 & .22 & ---- & .43 & .35 \\
\hline 8. Częstotliwość występowania fantazji seksualnych & -.10 & .16 & .22 & .39 & .40 & .15 & .39 & ---- & .42 \\
\hline $\begin{array}{l}\text { 9. Postawy wobec przygodnego, niezobowiązującego } \\
\text { seksu }\end{array}$ & .09 & .44 & .43 & .30 & .47 & .42 & .14 & .35 & ---- \\
\hline
\end{tabular}

Uwaga. Korelacje dla mężczyzn $(N=202)$ podano powyżej przekątnej, natomiast dla kobiet $(N=204)$ poniżej. Wszystkie korelacje o wyniku większym niż .15 są istotne dla alfa $=.05$ (dwustronnie).

Na podstawie zawartości pozycji całość miary socjoseksualności określiliśmy Inwentarzem Orientacji Socjoseksualnej (SOI). Narzędzie przedstawia załącznik B. Osoby, które uzyskały wysokie wyniki w badaniu prowadzonym przy użyciu SOI, mają tendencję do posiadania nierestrykcyjnej orientacji socjoseksualnej. Takie osoby najczęściej uprawiały seks

$\mathrm{z}$ większą liczbą partnerów w ostatnim roku, przewidywały większą liczbę partnerów w przyszłości, podejmowały częściej jednorazowe, niezobowiązujące kontakty seksualne, częściej fantazjowały o seksie z inną osobą niż obecny partner i prezentowały bardziej liberalne postawy wobec niezobowiązującego, jednorazowego seksu aniżeli osoby o restrykcyjnej orientacji socjoseksualnej, które uzyskały niższe wyniki.

SOI pozwala na rzetelną ocenę indywidualnych różnic między restrykcyj$n q$ a nierestrykcyjna orientacją socjoseksualną, zatem możemy przypuszczać, że osoby nierestrykcyjne w stosunku do osób restrykcyjnych uprawiają seks (a) na wcześniejszym etapie romantycznych związków, (b) z więcej niż jednym partnerem w tym samym czasie oraz (c) charakteryzują się mniejszym zaangażowaniem, niską inwestycją w związek oraz słabymi więziami emocjonalnymi w relacji z partnerem. W badaniach 2, 3 i 4 weryfikowaliśmy te założenia.

\section{Walidacja: Badanie 2}

Zadeklarowane oddanie i emocjonalna bliskość zazwyczaj wymagają czasu, aby zostały rozwinięte wraz ze zmianami zachodzącymi w romantycznym związku (Berseheid, 1983; H. H. Kelley, 1983; Rubin, 1970). Zatem jeżeli nierestrykcyjne osoby są bardziej skłonne uprawiać seks bez silnej więzi emocjonalnej, powinny podejmować tego typu kontakty na wcześniejszym etapie niż osoby restrykcyjne. 
W celu sprawdzenia prawdziwości tego założenia do wypełnienia SOI zaprosiliśmy pary będące w stałych związkach. Następnie każda z osób miała określić, czy uprawiała już seks z obecnym partnerem, jeżeli tak, to po jakim czasie trwania związku rozpoczęli oni współżycie seksualne. Za pomocą ankiet indywidualnych (dane Q) i partnerskich (dane L), dotyczących czasu, jaki musiał upłynąć do momentu pierwszego stosunku seksualnego, doszliśmy do wniosku, że szczegółowe zbadanie zbieżności naszych założeń jest możliwe.

\section{Metoda}

\section{Uczestnicy}

W badaniu wzięły udział 144 pary będące w stałym związku (144 kobiety i 144 mężczyzn), a przynajmniej jedna osoba z każdej pary była uczestnikiem kursu Wprowadzenie do psychologii na Texas A\&M University.

\section{Procedura}

Uczestnicy zgłaszali się do dużej sali doświadczalnej. W każdej sesji brało udział od 10 do 15 par, które zostały poinformowane, że będą wypełniać anonimowy kwestionariusz, dotyczący aspektów ich dotychczasowego społecznego i seksualnego zachowania. Aby zapewnić anonimowość, uczestnicy badania zostali (a) fizycznie rozdzieleni przed wypełnieniem kwestionariuszy, (b) poproszeni o niepodpisywanie kartek, (c) poinformowani o możliwości umieszczenia kwestionariusza w nieoznakowanych kopertach, oraz (d) poproszeni o pozostawienie kart w pudełku zbiorczym dla wszystkich kwestionariuszy. Po zakończeniu badania uczestnikom podziękowano i dano możliwość zadawania pytań i zgłaszania uwag.

\section{Pomiar}

Inwentarz Orientacji Socjoseksualnej. Aby utworzyć pojedynczy, składowy wynik dla SOI, odpowiedzi uczestników dla każdej z pięciu pozycji markera zostały znormalizowane poprzez wystandaryzowanie wewnątrz badanych prób kobiet i mężczyzn. Pięć pozycji zostało połączonych w celu uzyskania wyniku ogólnego dla SOI. Podobnie jak w badaniu 1, analiza czynnika osi głównej wykazała, że wszystkie pięć pozycji obciążonych było wysokim (powyżej .50) wynikiem na jednym, stałym czynniku.

Odbycie pierwszego stosunku. Okoliczności i czas trwania związku przed rozpoczęciem współżycia seksualnego oceniały dwa pytania: (a) „Czy kiedykolwiek uprawiałeś seks z aktualnym partnerem?” (odpowiedz tak lub nie), oraz 
(b) „Jeśli tak, to jak długo (w tygodniach) spotykałeś się z obecnym partnerem przed rozpoczęciem z nim/nią współżycia seksualnego?”

Tabela 2. Wartości ładunków czynnikowych dla pierwszego stałego faktora. Badanie 1.

\begin{tabular}{|l|c|}
\hline \multicolumn{1}{|c|}{ Zmienna } & tadunek czynnikowy \\
\hline Częstotliwości uprawiania seksu w ostatnim miesiącu & .19 \\
Liczba partnerów życiowych & .82 \\
Liczba partnerów w ubiegłym roku & .73 \\
Liczba pożądanych partnerów & .40 \\
Przewidywana liczba partnerów & .52 \\
Liczba stosunków seksualnych na jedną noc & .64 \\
Częstotliwość występowania myśli seksualnych & .41 \\
CZęstotliwość występowania fantazji seksualnych & .54 \\
Postawy wobec przygodnego, niezobowiązującego seksu & .73 \\
\hline
\end{tabular}

Uwaga. $N=406$ (204 kobiety i 202 mężczyzn).

\section{Wyniki i dyskusja}

W celu określenia, czy osoby wykazujące nierestrykcyjną orientację socjoseksualną były bardziej skłonne do podejmowania relacji seksualnych we wcześniejszym etapie trwania ich związku, najpierw zidentyfikowaliśmy te pary, które uprawiały seks ze swoim partnerem. Dziewięćdziesiąt pięć par $(66 \%$ próby) zadeklarowało aktywność seksualną w niezależnych, indywidualnych odpowiedziach ${ }^{5}$. Wyniki dla SOI, uzyskane przez partnerów, były ze sobą dodatnio i silnie skorelowane (w obrębie diady, $r=.30$ ).

Następnie zbadano korelacje między wynikami SOI dla aktywnych seksualnie osób z ich wynikami z pomiarów indywidualnych oraz pomiarów ich partnerów, skupiając się na czasie trwania związku, po upływie którego para po raz pierwszy ze sobą współżyła. Najpierw skorelowaliśmy wyniki SOI dla kobiet z ich własnymi odpowiedziami i odpowiedziami ich partnerów dotyczącymi tego, po jakim czasie trwania związku para rozpoczęła współżycie seksualne. Następnie skorelowaliśmy wyniki SOI dla mężczyzn z ich własnymi odpowiedziami i odpowiedziami partnerek dotyczącymi tego, jak długo para spotykała się przed rozpoczęciem współżycia. Wyżej opisane korelacje przedstawia tabela 3.

${ }^{5}$ W tym i w kolejnym badaniu porównano wyniki SOI dla par aktywnych i nieaktywnych seksualnie. We wszystkich badaniach osoby nieaktywne seksualnie uzyskiwały niższe wyniki niż osoby aktywne seksualnie (wszystkie ts $>2, \mathrm{p}<0,05$ ). 
Według danych zaprezentowanych w tabeli 3 mężczyźni i kobiety, których wyniki w pomiarze przy wykorzystaniu SOI były wyższe (osoby nierestrykcyjne), rozpoczynały współżycie seksualne we wcześniejszym okresie trwania ich relacji z partnerem niż osoby, które uzyskiwały wyniki niższe (osoby restrykcyjne). To, jak długo para spotykała się przed pierwszym stosunkiem seksualnym, było istotne niezależnie od tego, czy powoływać się na dane indywidualne (Q), czy partnerskie (L). Rzeczywiście, skala relacji między socjoseksualnością a podjęciem pierwszego stosunku była praktycznie identyczna dla obu typów danych. Mimo że korelacja między SOI i długością trwania związku przed rozpoczęciem współżycia wydaje się przyjmować wyższą wartość w przypadku kobiet niż mężczyzn, testy dla korelacji zależnych (Cohen, Cohen, 1983) wykazały, że nie była ona istotnie wyższa ani dla danych z raportów indywidualnych, ani raportów partnerskich; wyniki prezentowały się w następujący sposób: $t s$ (92) $<1,15$, ns.

Ponieważ decyzja o rozpoczęciu współżycia seksualnego zazwyczaj wymaga zgody obu partnerów, przeprowadziliśmy dwie częściowe korelacje. Najpierw skorelowaliśmy uzyskane przez kobiety wyniki SOI z wynikami raportów partnerskich ich mężczyzn, mając na uwadze długość trwania związku przed rozpoczęciem współżycia seksualnego, równolegle kontrolując statystyczną wartość ich wyników dla SOI. Następnie skorelowaliśmy wyniki SOI mężczyzn z wynikami uzyskanymi w raportach partnerskich przez ich kobiety, mając na uwadze długość trwania związku przed rozpoczęciem współżycia seksualnego, jednocześnie kontrolując ich wyniki dla SOI. W sytuacji, kiedy efekt dla zmiennej, jaką był wynik SOI uzyskany przez mężczyzn, został usunięty, wysokie korelacje między kobiecą socjoseksualnością a raportami partnerskimi, dotyczące tego, kiedy nastąpił pierwszy kontakt seksualny (częściowe $r$ $=-.32, p<0,001)$, nie zmieniły się. Jednakże, kiedy efekt dla tej samej zmiennej uzyskiwanej przez kobiety został usunięty, korelacja między męską socjoseksualnością a raportami partnerskimi dotyczącymi tego, kiedy nastąpił pierwszy kontakt seksualny (częściowe $r=-.05, n s$ ), przestała osiągać tak wysokie wartości. Uzyskane wyniki pokazują, że socjosesksualność kobiet znacznie wpływa na moment wystąpienia seksu w związku. Te wyniki nie są zaskakujące, zwłaszcza mając na uwadze, że to partner z bardziej restrykcyjną orientacją socjoseksualną może dyktować, czy i kiedy dojdzie do współżycia seksualnego. Jak już wspominaliśmy, to kobiety są bardziej restrykcyjne od mężczyzn. W związku z tym powinny być one bardziej restrykcyjne w większości heteroseksualnych diad (por. Peplau i in., 1977). 
Jeffry A. Simpson, Steven W. Gangestad, Emilia Aksamit Indywidualne różnice...

Tabela 3. Korelacja Inwentarza Orientacji Socjoseksualnej (SOI) z Indywidualnymi i Partnerskimi Raportami na temat długości trwania związku przed rozpoczęciem wspótżycia seksualnego: Badanie 2.

\begin{tabular}{|ccc|}
\hline \multicolumn{4}{|c|}{ Długość trwania związku przed rozpoczęciem współżycia seksualnego } \\
\hline Wynik SOI & Raport indywidualny & Raport partnerski \\
\hline Kobiety & $-.32^{* *}$ & $-.35^{* *}$ \\
Mężczyźni & $-.20^{*}$ & $-.18^{*}$ \\
\hline
\end{tabular}

$\mathrm{N}=95$ par. Wszystkie korelacje są jednostronne.

${ }^{*} p<.05 .{ }^{* *} p<.001$.

\section{Walidacja: Badanie 3}

Jedną z cech wyraźnego zaangażowania jest restrykcyjna postawa wobec seksu tylko w obrębie aktualnego związku (H. H. Kelley, 1983). Jeżeli osoby restrykcyjne są mniej skłonne do rozpoczęcia współżycia seksualnego bez zaangażowania niż osoby nierestrykcyjne, powinny one być mniej skłonne do angażowania się w seks z więcej niż jednym partnerem romantycznym w tym samym czasie.

W celu przetestowania trafności drugiego założenia, na samym początku musieliśmy przeprowadzić pomiar przy użyciu SOI, a następnie poprosiliśmy respondentów o sprecyzowanie, czy współżyją z obecnym partnerem bądź współżyli z ostatnim partnerem. Jeżeli tak, to czy jednocześnie będąc $\mathrm{w}$ związku zdarzyło im się uprawiać seks z kimś innym niż obecny/były partner.

\section{Metoda}

\section{Uczestnicy}

W badaniu w ramach kursu Wprowadzenie do psychologii na Texas A\&M University wzięło udział 605 osób (296 kobiet i 309 mężczyzn).

\section{Procedura}

Procedury zastosowane w badaniu 3 były takie same jak te w badaniu 1. Oprócz podania informacji na temat płci, wieku i określenia przez respondenta, czy uprawiał seks z obecnym (bądź ostatnim) partnerem, osoby badane udzielały odpowiedzi dla SOI. Po uzyskaniu tych danych przeprowadziliśmy pomiar głównej zmiennej zależnej. 


\section{Pomiar}

Częstość podejmowania relacji seksualnych poza obecnym związkiem ocenialiśmy zadając pytanie: „Czy w czasie kiedy byłeś w związku, zdarzyło Ci się uprawiać seks z kimś innym niż twój partner?" $(1=$ tak, $0=n i e)$.

\section{Wyniki i dyskusja}

Starając się określić, czy osoby nierestrykcyjne były bardziej skłonne do uprawiania seksu $\mathrm{z}$ więcej niż jedną osobą w tym samym czasie, najpierw zidentyfikowaliśmy te osoby, które uprawiały seks z aktualnym lub ostatnim partnerem. 345 osób (57\% próby) spełniło to kryterium. Dla tej podgrupy wyliczyliśmy współczynnik korelacji punktowo-dwuseryjnej między wynikami uzyskanymi dla SOI a wynikami raportów indywidualnych, wskazując, czy respondenci odbywali stosunki seksualne poza ich aktualnym lub ostatnim związkiem.

Korelacje były wyraźnie widoczne, a ich wyniki skłaniały się w przewidywanym kierunku w próbach mężczyzn i kobiet; dla mężczyzn, $r(183)=.27$, $p<.001$; dla kobiet $r(162)=.33, p<.001$. W szczególności w przypadku osób, których wyniki dla SOI były wyższe w stosunku do tych, których wyniki były niższe, istniało znacznie większe prawdopodobieństwo podejmowania relacji seksualnych z osobą inną niż obecny lub ostatni partner.

\section{Walidacja: Badanie 4}

Jeśli, jak sugerowaliśmy wcześniej, osoby restrykcyjne są mniej skłonne do podejmowania współżycia seksualnego bez zaangażowania, tworzenia silnych więzi emocjonalnych i romantycznych relacji niż osoby nierestrykcyjne, to romantyczne relacje tych pierwszych powinny charakteryzować się wysokim zaangażowaniem, poświęceniem, miłością i współzależnością. W celu zbadania trzeciej przewidywanej przez nas zależności do badania wybraliśmy pary aktywne seksualnie, które udzieliły odpowiedzi dla SOI, oraz miar, które oceniały cztery poniższe wymiary.

\section{Metoda}

\section{Uczestnicy}

W badaniu wzięły udział 144 pary, które uczestniczyły w badaniu 2 .

\section{Procedura}

Procedury zastosowane w badaniu były takie same jak opisane w badaniu 2. Osoby badane udzielały odpowiedzi dla SOI, następnie określały, jak 
długo trwa ich związek i czy rozpoczęły już współżycie seksualne. Na końcu uczestnicy zostali poproszeni o wypełnienie kwestionariuszy dla czterech miar ujętych w badaniu.

\section{Pomiar}

Skala zaangażowania. Poziom zobowiązania wobec obecnego partnera oceniony został przy użyciu Skali Zaangażowania Lunda (Lund, 1985). W tym przypadku trafność fasadowa określona została miarą 9-pozycyjną z 7-stopniową skalą odpowiedzi Likerta $(1=w$ ogóle się nie zgadzam, $7=z$ decydowanie się zgadzam).

Skala inwestycji. Poziom inwestycji w obecny związek mierzony był przy użyciu zaadaptowanej Skali Inwestycji (Rusbult, 1980). W tym przypadku trafność fasadowa określona została miarą 8-pozycyjną z 7-stopniową skalą odpowiedzi $(1=$ ani troche, $7=$ bardzo $)$.

Skala miłości. Poziom uczucia miłości, jaką respondent obdarza aktualnego partnera, zmierzony został przy użyciu 9-pozycyjnej wersji Skali Miłości Rubina (Rubin, 1970) z 9-stopniową skalą odpowiedzi $(1=z$ decydowanie się nie zgadzam, 9 = zdecydowanie się zgadzam).

Skala zależności. Pomiar psychologicznej i emocjonalnej zależności od obecnego partnera został dokonany przy użyciu Skali Zależności (Fei, Berscheid, 1977). W tym przypadku trafność fasadowa zmierzona została przy wykorzystaniu miary 16-pozycyjnej z 7-stopniową skalą odpowiedzi $(1=$ zdecydowanie się nie zgadzam, $7=$ zdecydowanie się zgadzam).

\section{Wyniki i dyskusja}

W celu określenia, czy relacja osób z restrykcyjną orientacją socjoseksualną, które uprawiały seks ze swoim partnerem, wymaga większych inwestycji, charakteryzuje się większym zaangażowaniem, współzależnością i uczuciem miłości w porównaniu do aktywnych seksualnie osób o orientacji nierestrykcyjnej, ponownie zidentyfikowaliśmy 95 par, w których partnerzy deklarowali uprawiać ze sobą seks. Wstępna analiza czterech miar relacji ujawniła, że były one ze sobą silnie skorelowane (dla obu płci $r$ s wahało się od .70 do .87). Z tego powodu na początku próbowaliśmy ustalić, czy jeden wymiar może być podstawą dla czterech miar relacji. Aby to zrobić, przeprowadziliśmy analizę czynnikową dwóch głównych osi (SPSSX PA2). Najpierw wykonaliśmy analizę czynnikową dla odpowiedzi udzielonych przez mężczyzn w obszarze czterech miar relacji. Następnie dokonaliśmy tych samych analiz dla odpowiedzi udzielonych 
przez kobiety. Na podstawie testu osypiska (Cattell, 1966) i współczynnika interpretacyjności w obrębie każdej z płci pojawił się jeden dominujący wynik. W przypadku mężczyzn każda miara związku uzyskała wynik o współczynniku przekraczającym $.80 \mathrm{w}$ dominującym wymiarze. U kobiet wszystkie cztery wyniki przekroczyły .70 .

$\mathrm{Na}$ podstawie powyższych wyników wystandaryzowaliśmy wszystkie cztery miary (poprzez normalizacje $Z$-score) w obrębie płci. W celu uzyskania bardziej rzetelnych szacunków dla wartości relacji między SOI a wymiarem głównym połączyliśmy cztery wystandaryzowane relacje miar, tworząc bardziej rzetelny i złożony wskaźnik odzwierciedlający zmienność leżącą u jego podstaw. Wysokie wyniki uzyskane w obrębie tego wskaźnika odzwierciedlały wysokie wyrażanie uczucia miłości, zależność, zaangażowanie i inwestowanie w relację, natomiast niskie wyniki wskazywały na tendencje odwrotne. Następnie skorelowaliśmy SOI ze złożonym wskaźnikiem.

Jak przedstawiono w tabeli 4, wyniki SOI uzyskiwane przez mężczyzn korelują wysoko zarówno z własnymi $(r=-.61, p<.001)$, jak i z udzielonymi przez partnerki $(r=-.35, p<.001)$ odpowiedziami dla wskaźnika złożonego. Wyniki SOI kobiet również korelowały wysoko z własnymi $(r=-.50, \mathrm{p}<.001)$ i udzielonymi przez partnerów $(r=-.33, p<.001)$ odpowiedziami w obrębie opisanego wskaźnika. Na podstawie niezależnych wyników obojga partnerów można stwierdzić, że osoby z restrykcyjną orientacją socjoseksualną, w przeciwieństwie do tych z nierestrykcyjną, wydają się bardziej zaangażowane w relacje seksualne, charakteryzujące się wyrażaniem uczucia miłości, zależnością i większym inwestowaniem w związek. Zbadanie korelacji rzędu zerowego między SOI a każdą z czterech miar rozpatrywanych oddzielnie potwierdziło ten wniosek. Niezależnie od tego, czy opieramy się na wynikach jednej osoby, czy wynikach uzyskanych przez oboje partnerów, osoby restrykcyjne, w stosunku do tych nierestrykcyjnych, mają skłonność do angażowania się w relacje seksualne charakteryzujące się zaangażowaniem, współzależnością i uczuciem miłości.

Wyniki te mogą być związane $\mathrm{z}$ różnicami w średniej długości trwania związku. Jeżeli nierestrykcyjne osoby mają partnerów przez krótszy czas, to może to tłumaczyć, dlaczego ich relacje przeważnie charakteryzować się będą mniejszym uczuciem miłości, słabszym zaangażowaniem i niezależnością oraz mniejszym inwestowaniem w relacje. Aby wyeliminować ten potencjalnie mylący rezultat, skorelowaliśmy wyniki czterech miar relacji z wynikami SOI, uwzględniając długość trwania związku. Wszystkie korelacje były nadal istotne statystycznie, nawet kiedy efekt długości trwania związku został częściowo 
wykluczony (wszystkie $r$ s większe niż $-.30, p<0,01$, dla kobiet; $-.47, p<.001$, dla mężczyzn).

Tabela 4. Korelacja pomiędzy wynikami SOI dla kobiet i mężczyzn a raportami indywidualnymi i partnerskimi w obszarze miar relacji: Badanie 4

\begin{tabular}{|c|c|c|c|c|}
\hline \multirow[b]{2}{*}{ Miary relacji } & \multicolumn{2}{|c|}{ Mężczyźni SOI } & \multicolumn{2}{|c|}{ Kobiety SOI } \\
\hline & $\begin{array}{l}\text { Mężczyźni - pomiar } \\
\text { indywidualny }\end{array}$ & $\begin{array}{l}\text { Kobiety - pomiar } \\
\text { partnerski }\end{array}$ & $\begin{array}{l}\text { Kobiety - pomiar } \\
\text { indywidualny }\end{array}$ & $\begin{array}{l}\text { Mężczyźni - pomiar } \\
\text { partnerski }\end{array}$ \\
\hline $\begin{array}{l}\text { Miłość } \\
\text { Inwestycja } \\
\text { Zaangażowanie } \\
\text { Zależność } \\
\text { Złożony wskaźnik }\end{array}$ & $\begin{array}{l}-.61^{* * \star} \\
-.50^{\star * \star} \\
-.57^{\star * \star} \\
-.59^{\star \star \star} \\
-.61^{* * \star}\end{array}$ & $\begin{array}{l}-.20^{*} \\
-.35^{* *} \\
-.36^{* * *} \\
-.29^{* *} \\
-.35^{*}\end{array}$ & $\begin{array}{l}-.44^{\star * \star} \\
-.36^{* \star *} \\
-.44^{\star \star \star} \\
-.49^{\star \star \star} \\
-.50^{\star * \star}\end{array}$ & $\begin{array}{l}-.24^{*} \\
-.36^{\star * *} \\
-.36^{\star \star \star} \\
-.28^{\star *} \\
-.33^{\star * *}\end{array}$ \\
\hline
\end{tabular}

Uwaga. N = 95 mężczyzn i 95 kobiet. Wszystkie korelacje są jednostronne.

${ }^{*} \mathrm{p}<.05$. ${ }^{* *} \mathrm{p}<.01$. *** $\mathrm{p}<.001$.

\section{Trafność dyskryminacyjna: Badanie 5}

Można poddać pod dyskusję to, czy indywidualne różnice w skłonności do podejmowania niezobowiązujących relacji seksualnych odzwierciedlają różnice w poziomie ogólnego popędu seksualnego (np. J. Kelley, 1978). Być może nierestrykcyjne osoby mają jednakowo wyższy poziom popędu seksualnego, w przeciwieństwie do osób restrykcyjnych i jest to najważniejszy czynnik, który pozwala im uprawiać seks bez zaangażowania emocjonalnego i inwestycji w relacje.

Jeżeli gotowość do uprawiania niezobowiązującego seksu stanowi unikalny wymiar psychologiczny, niezwiązany z ogólnym zainteresowaniem seksem, to socjoseksualność nie powinna znacznie współzmieniać się z zachowaniami odzwierciedlającymi popęd seksualny (np. częstością aktywności seksualnych w ostatnim czasie), przynajmniej wśród aktywnych seksualnie par. Na podstawie zarówno teoretycznych (np. Mellen, 1981), jak i empirycznych (np. Hendrick i in., 1985; Snyder i in., 1986) założeń potrzeba częstego seksu, która może być zaspokojona w bliskich i trwałych relacjach, powinna odzwierciedlać inne motywy psychologiczne aniżeli chęć do podejmowania niezobowiązujących relacji seksualnych z różnymi partnerami. Stopień, do którego SOI pozwala ocenić tę ostatnią postać zmienności, nie powinien znacznie korelować ze wskaźnikami odzwierciedlającymi całkowitą miarę aktywności seksualnej par będących w związku. Jednakże, o ile osoby nierestrykcyjne są bardziej skłonne podejmować niezobowiązujące relacje seksualne poza obecnym związkiem 
(badanie 3), to wynik SOI powinien korelować umiarkowanie z miarą częstotliwości uprawiania seksu wśród seksualnie nieaktywnych par.

Aby sprawdzić te założenia, poprosiliśmy pary pozostające w związku o wypełnienie SOI. Każdy członek diady określił, czy współżyje seksualne $\mathrm{z}$ aktualnym partnerem i ile razy w ciągu ostatniego miesiąca uprawiał seks. Ponownie, od każdej z osób indywidualnie (dane Q), jak i od par (dane L), zebraliśmy dane dotyczące częstotliwości uprawiania seksu, co umożliwiło nam dokładne zweryfikowanie naszych założeń.

\section{Metoda}

\section{Uczestnicy}

W badaniu wzięło udział 241 par (241 kobiet i 241 mężczyzn) będących w stałych związkach, a przynajmniej jedna osoba z każdej pary była uczestnikiem kursu Wprowadzenie do psychologii na Texas A\&M University.

\section{Procedura}

Uczestnicy zgłaszali się do dużej sali doświadczalnej. W każdej sesji brało udział od 5 do 15 par, które zostały poinformowane, że będą wypełniać anonimowy kwestionariusz, dotyczący aspektów ich dotychczasowego społecznego i seksualnego życia. Aby zapewnić anonimowość, zastosowaliśmy te same procedury co w badaniu 2. Po zakończeniu badania uczestnikom podziękowano i dano możliwość zadawania pytań i zgłaszania uwag. Na początku badania uczestnicy wypełniali SOI, a następnie odpowiadali na pytania pozwalające zbadać niżej wymienione zmienne.

\section{Pomiar}

Zakres wspólżycia seksualnego w związu. Częstotliwość występowania seksu w związku ocenialiśmy na podstawie pozycji: „Czy kiedykolwiek uprawiałeś seks z aktualnym partnerem?” (odpowiedz tak lub nie).

Częstotliwość wspótżycia seksualnego w ostatnim miesiącu. Częstotliwość aktywności seksualnej w minionym miesiącu określaliśmy na podstawie pytania: „Ile razy uprawiałeś seks w ciągu ostatniego miesiąca?”

\section{Wyniki i dyskusja}

Przed określeniem, czy orientacja socjoseksualna osób była stosunkowo ortogonalna względem całkowitej liczby aktywności seksualnych, najpierw ziden- 
tyfikowaliśmy te pary, które, na podstawie raportów obu partnerów, uprawiały seks. 166 par (69\% próby) było aktywnych seksualnie.

Następnie zbadaliśmy korelacje między wynikami SOI dla aktywnych seksualnie osób z ich indywidualnymi wynikami (dane Q) i wynikami ich partnerów (dane L) dotyczącymi całkowitej częstotliwości seksu w ciągu ostatniego miesiąca. Wyniki SOI dla kobiet nie korelowały z wynikami uzyskanymi z ich indywidualnych raportów $(r=.08)$ ani z wynikami z raportów partnerskich $(r=-.02)$ w obszarze częstotliwości odbywania stosunku seksualnego w ciągu ostatniego miesiąca. W podobny sposób przedstawiają się wyniki SOI dla próby mężczyzn, które również nie korelowały w obszarze częstotliwości uprawiania seksu z wynikami raportów indywidualnych $(r=.15)$ oraz raportów partnerskich $(r=.01)$.

Ponadto zmierzyliśmy stosunek między SOI a samodzielnie ocenioną częstotliwością seksu wśród par $(N=75)$, które jeszcze nie współżyły ze sobą. Oczywiście, każda relacja seksualna jednostki musiała nastąpić poza obecnym związkiem. Jeżeli zatem osoby nierestrykcyjne są bardziej skłonne do podejmowania niezobowiązujących relacji seksualnych poza ich obecnym związkiem, należy spodziewać się wyższej korelacji wyników uzyskanych dla SOI $\mathrm{z}$ indywidualną oceną częstości kontaktów seksualnych każdego członka nieaktywnej seksualnie pary. Zgodnie z oczekiwaniami, pojawiły się wiarygodne relacje między socjoseksualnością i występowaniem stosunków seksualnych poza nieaktywnymi seksualnie parami (dla mężczyzn, $r=.28, p<0,05$; dla kobiet, $r=.53, p<0,001)$.

Korelacja między wynikami SOI a częstotliwością uprawiania seksu była znacząco wyższa dla kobiet w parach nieaktywnych seksualnie niż dla kobiet będących w związkach, w których partnerzy współżyją ze sobą $(z=3.61$, $p<.001)$. Silniejsza korelacja dla kobiet będących w nieaktywnych seksualnie związkach wydaje się związana z faktem, że nierestrykcyjne kobiety są bardziej skłonne do podejmowania relacji seksualnych poza ich obecnym związkiem. Niewielka zależność pomiędzy częstotliwością seksu a wynikami SOI w próbie kobiet będących w aktywnych seksualnie związkach pokazuje, że restrykcyjne i nierestrykcyjne kobiety generalnie nie różnią się pod względem zainteresowania seksem per se. Oczywiste jest, że jeżeli socjoseksualność odzwierciedla jedynie poziom ogólnego popędu seksualnego, oczekiwać należy, by wyniki SOI współzmieniały się z częstotliwością seksu w obu rodzajach relacji. Ponieważ tak nie jest, indywidualne różnice w socjoseksualności wydają się różne od tych leżących u podstaw ogólnego poziomu popędu seksualnego. 


\section{Korelacja z innymi miarami seksualności: Badanie 6}

Znanych jest kilka innych miar opisujących szeroki zakres postaw i zachowań seksualnych (patrz Davis, Yarber, Davis, 1988). Eysenck (1976) na przykład opracował wszechstronny inwentarz do oceny 12 unikalnych indywidualnych różnic charakteryzujących seksualność jednostki (patrz również Hendrick i in., 1985). Niektóre z tych wymiarów wydają się oceniać indywidualne różnice w rozwiązłości seksualnej oraz pragnieniach różnorodności seksualnej (np. permisywizm seksualny, seks bezosobowy). O ile socjoseksualność odzwierciedla stopień, w jakim ludzie są skłonni zgadzać się na seks przed powstaniem silnej emocjonalnej więzi, różnice indywidualne dla wskazanych wymiarów powinny umiarkowanie korelować z SOI. Inne obszary ujawniają indywidualne różnice w ogólnym poziomie satysfakcji seksualnej (np. zadowolenie), poczucie winy związane z seksem (np. neurotyczny seks) i lęk związany ze współżyciem (np. nieśmiałość seksualna). Ponieważ indywidualne różnice w gotowości do podejmowania niezobowiązujących relacji seksualnych nie powinny być silnie i głównie powiązane z poczuciem satysfakcji, winy czy lęku w doświadczaniu relacji seksualnej, różnice indywidualne w tych wymiarach nie powinny znacznie współzmieniać się z wynikami SOI.

W celu pomiaru tych związków poprosiliśmy respondentów o wypełnienie Inwentarza Orientacji Socjoseksualnej oraz Inwentarza Postaw Wobec Seksu, ang. Eysenck's lnventory of Attitudes to Sex (Eysenck, 1976).

\section{Metoda}

\section{Uczestnicy}

W badaniu w wzięło udział 199 kobiet i 197 mężczyzn. Wszyscy byli uczestnikami kursu Wprowadzenie do psychologii na Texas A\&M University.

\section{Procedura}

Uczestnicy zgłaszali się do dużej sali doświadczalnej. W każdej sesji brało udział od 20 do 30 osób, które zostały poinformowane, że będą wypełniać anonimowy kwestionariusz dotyczący ich społecznych, seksualnych i romantycznych postaw oraz zachowań. Aby zapewnić anonimowość, zastosowaliśmy te same procedury co w badaniu 1. Po zakończeniu badania uczestnikom podziękowano i dano możliwość zadawania pytań i zgłaszania uwag. Uczestnicy w pierwszej kolejności wypełnili SOI, informując o swoim wieku, płci oraz statusie związku, a następnie odpowiedzieli na pytania określające opisane poniżej miary zawarte w badaniu. 
Jeffry A. Simpson, Steven W. Gangestad, Emilia Aksamit Indywidualne różnice...

\section{Pomiar}

Inwentarz Postaw Wobec Seksu Eysencka (1976). Narzędzie składa się z 12 rozbudowanych skali, których przykłady podane są poniżej:

1. Permisywizm: „Lepiej nie uprawiać seksu przed ślubem”.

2. Satysfakcja: „Jestem zadowolony ze swojego życia seksualnego".

3. Neurotyczny seks: „Po seksie miałem poczucie winy”.

4. Seks bezosobowy: „Wolałbym co noc mieć nowego partnera seksualnego".

5. Pornografia: „Lubię patrzeć na zdjęcia prezentujące nagość”.

6. Lęk seksualny: „Czuję się nerwowy w kontakcie z osobami przeciwnej płci".

7. Pruderia: ,Żarty o seksie budzą we mnie wstręt”.

8. Dominacja-uległość: „Moi rodzice wpłynęli na zahamowanie mojej seksualności".

9. Seksualne obrzydzenie: „Niektóre formy uprawiania seksu obrzydzają mnie".

10. Seksualne podniecenie: „Bardzo łatwo jest mi podniecić się seksualnie".

11. Seks fizyczny: „Seks daje mi zdecydowanie najwięcej przyjemności w życiu".

12. Seks agresywny: „Zazwyczaj czuję agresję w kontakcie seksualnym z moim partnerem".

Pozycje 1 i 8 zostały odwrócone. Wszystkie pozycje były oceniane na skali trzypunktowej $(1=$ prawda/tak, 2 = nie mam zdania, $3=$ fatsz $/$ nie $)$. Wynik dla każdej z 12 skali został obliczony zgodnie z procedurami opisanymi przez Eysencka (1976), oddzielnie dla kobiet i mężczyzn.

\section{Wyniki i dyskusja}

Korelacja wyników SOI z wynikami uzyskanymi na skali Eysencka zaprezentowana została w tabeli 5 . W większości wartość korelacji tych wyników była podobna dla kobiet i mężczyzn. Zgodnie z założeniami, wyniki dla SOI korelowały umiarkowanie ze skalami permisywizmu i seksu bezosobowego. Ponadto wyniki dla SOI korelowały umiarkowanie również ze skalą seksu fizycznego, seksu agresywnego, pornografii oraz pruderii (pozycja odwrócona). Zgodnie z przewidywaniami, wyniki dla SOI korelowały ujemnie ze skalami mierzący- 
mi ogólny poziom zadowolenia z seksu, czyli skalą satysfakcji (np. satysfakcja seksualna), lęku seksulanego (np. nieśmiałości) oraz skalą neurotycznego seksu (np. poczucie winy).

Wyniki te wskazują, że oprócz prezentowania bardziej liberalnych postaw wobec przedmałżeńskiego i bezosobowego seksu z różnymi partnerami, osoby o nierestrykcyjnej orientacji socjoseksualnej są bardziej skłonne czerpać radość z seksu fizycznego, agresywnego i pornografii aniżeli osoby o orientacji restrykcyjnej. Jednocześnie pomiar socjoseksualności jest wprost powiązany z satysfakcją seksualną, lękiem przed seksem i poczuciem winy. Ostatnie z zaprezentowanych wyników są godne uwagi, ponieważ wskazują, że indywidualne różnice w odczuwaniu satysfakcji seksualnej, lęku przed seksem i poczucia winy nie tłumaczą, dlaczego osoby o restrykcyjnej orientacji socjoseksualnej w znacznie mniejszym stopniu podejmują niezobowiązujące relacje seksualne.

Tabela 5. Korelacja pomiędzy wynikami Inwentarza Orientacji Socjoseksualnej a wynikami 12-stopniowej Skali Seksualności Eysencka: Badanie 6

\begin{tabular}{|l|c|c|}
\hline \multicolumn{1}{|c|}{ Skale Eysencka } & Mężczyźni & Kobiety \\
\hline Permisywizm & .32 & .47 \\
Seks bezosobowy & .54 & .54 \\
Neurotyczny seks & -.01 & .19 \\
Lęk seksualny/nieśmiałość & -.16 & .08 \\
Pruderia & -.28 & -.30 \\
Dominacja-uległość & -.06 & .25 \\
Seksualne obrzydzenie & -.08 & .24 \\
Seksualne podniecenie & -.04 & .24 \\
Seks fizyczny & .32 & .26 \\
Seks agresywny & .43 & .30 \\
Satysfakcja & -.05 & -.14 \\
Pornografia & .25 & .40 \\
\hline
\end{tabular}

Uwaga. $N=197$ mężczyzn i 199 kobiet. Wszystkie korelacje większe niż 15 są istotne przy

$\alpha=.05$ (obustronnie).

\section{Dyskusja}

Wyniki zaprezentowanych wyżej sześciu badań pozwalają stwierdzić, że różnice indywidualne w gotowości do podejmowania niezobowiązujących relacji seksualnych w sytuacji braku silnych więzi uczuciowych istnieją i można je skutecznie zmierzyć. Na podstawie analizy czynnikowej wyznaczyliśmy pięć wskaźników, dzięki którym można ocenić, w jakim stopniu dana osoba posiada ograniczoną (restrykcyjną) lub nieograniczoną (nierestrykcyjną) orientację socjoseksualną. Na podstawie tych pięciu wskaźników stworzyliśmy Inwentarz Orientacji Socjoseksualnej (SOI). 
Trafność zbieżna dla SOI została obliczona na podstawie wyników wskazujących, że osoby nierestrykcyjne w stosunku do restrykcyjnych zazwyczaj (a) wcześniej rozpoczynają współżycie seksualne w romantycznych związkach (badanie 2), (b) są skłonne uprawiać seks z więcej niż jednym partnerem w tym samym czasie (badanie 3), oraz (c) relacje seksualne tych osób charakteryzują się mniejszym nakładem inwestycji, niską zależnością od partnera oraz słabym poczuciem więzi emocjonalnej (badanie 4). Badanie 5 zapewniło trafność dyskryminacyjną, wskazując, że SOI nie koreluje z bezwzględną częstotliwością seksu wśród seksualnie aktywnych par. Badanie 6 wykazało, że SOI koreluje umiarkowanie z istniejącymi miarami seksualności, które oceniają powiązane z SOI teorie (np. permisywizm seksualny, seks bezosobowy), ale nie współzmienia się z miarami niepowiązanych zmiennych, tj. seksualna satysfakcja, poczucie winy i lęku.

Procedury walidacji odgrywają główną rolę w procesie rozwoju teorii, definicji i testów (Cronbach, Meehl, 1955). Wbrew przewidywaniom leżącym u podstaw popędu seksualnego, ale zgodnie z przewidywaniami o podstawie ewolucyjnej, w badaniu 5 wykazaliśmy, że różnice indywidualne w socjoseksualności były proporcjonalne do bazowych założeń popędu seksualnego lub ogólnego zainteresowania seksem per se. Warto podkreślić te wnioski, ponieważ wcześniejsze teoretyczne i empiryczne raporty dotyczące seksualności (np. Eysenck, 1976; Kelley J., 1978) zakładały, że źródła motywacji posiadania różnych partnerów seksualnych są bardzo podobne do tych leżących u podstaw bezwzględnej częstotliwości seksu. Wcześniejsze podejścia nie uwzględniały tego, że zachowanie seksualne występuje zwykle wewnątrz - a więc musi być interpretowane $\mathrm{w}$ ten sam sposób - społecznych i interpersonalnych kontekstów. Przez mylne łączenie gotowości do podejmowania niezobowiązujących relacji z pragnieniem uprawiania częstego seksu wcześniejsze badania nie rozdzieliły i nie oceniały socjoseksualności - zmiennej odzwierciedlającej nierozerwalnie interpersonalny charakter seksu.

Najważniejszym wynikiem naszych działań walidacyjnych jest pokazanie, że raporty indywidualne (dane Q) były poszerzane o niezależne raporty partnerskie (dane L), kiedy tylko było to możliwe. Według naszej wiedzy to badanie jest pierwszym, które pokazało, że indywidualne postawy i zachowania seksualne są konsekwentnie związane z zachowaniami w trwającym związku. Niestety, oba typy danych nie mogły być zbierane dla wszystkich badań. W świetle logicznych, praktycznych i etycznych rozważań wyniki badania 3 były w całości oparte na danych uzyskanych z raportów indywidualnych dotyczących aktywności seksualnych występujących również poza trwającym związkiem. 
Niemniej jednak, w trzech badaniach (2, 4 i 5) dane z raportów indywidualnych oraz partnerskich były podobne. Ponieważ dane uzyskane $\mathrm{z}$ raportów partnerskich zazwyczaj dopełniały i potwierdzały dane z raportów indywidualnych, wiarygodność zyskują badania opierające się wyłącznie na raportach indywidualnych.

Przeprowadzone badania pozwalają postawić kilka ważnych pytań dotyczących stabilności, pochodzenia i motywacji, leżących u podstaw indywidualnych różnic w socjoseksualności. W dalszej części tekstu postaramy się na nie odpowiedzieć.

\section{Czy socjoseskualność jest cechą stabilną?}

Czy różnice indywidualne w socjoseksualności odzwierciedlają stabilny, podobny do cechy wymiar, czy raczej przejściowe, indywidualne, zmienne różnice, których skutki odczuć można przede wszystkim na określonym etapie życia (lata randkowe)? Mimo że SOI dostarcza wiarygodnych wyników dla 2-miesięcznego testu-retestu ( $r=.94$; Simpson, Gangestad, 1989a), ostateczna odpowiedź na to pytanie nie może zostać jeszcze udzielona. Nawet jeśli socjoseksualność posiada stabilne, podobne do cech właściwości, jej fenotypowe przejawy mogą zmieniać się z biegiem życia. Na przykład w okresie randkowym różnice indywidualne w socjoseksualności mogą przejawiać się w gotowości do podejmowania relacji seksualnych przed rozwojem zaangażowania i silnych relacji emocjonalnych. Natomiast podczas okresu małżeństwa socjseksualność może być najlepiej widoczna w woli trwania w niezadowalającym związku małżeńskim (por. Newcomb, Bentler, 1981) lub w różnicach podatności do podejmowania pozamałżeńskich relacji z alternatywnym, atrakcyjnym partnerem (np. romanse pozamałżeńskie; Kelley H. H., Thibaut, 1978). W szczególności osoby nierestrykcyjne mogą być bardziej skłonne do zakończenia niesatysfakcjonujących relacji małżeńskich i podjęcia relacji pozytywnych. Przyszłe badania powinny sprawdzić, czy i jak fenotypowe przejawy socjoseksualności zmieniają się w ciągu całego życia.

\section{Jakie są możliwe źródła socjoseksualności?}

W oparciu na wynikach przeprowadzonych badań można założyć, że osoby z restrykcyjną orientacją socjoseksualną zwykle tworzą długotrwałe relacje charakteryzujące się wysokim zaangażowaniem i silnymi więziami emocjonalnymi, natomiast osoby nierestrykcyjne mają tendencje do tworzenia relacji 
krótkotrwałych, charakteryzujących się niższym zaangażowaniem oraz słabszymi więziami emocjonalnymi. W świetle powyższych rozważań warto zastanowić się, jakie mogą być zasadnicze źródła indywidualnych różnic w socjoseksualności.

Teoretycy sugerują, że różne rodzaje doświadczeń w okresie dzieciństwa mogą tworzyć indywidualne różnice w preferowaniu długotrwałych i zobowiązujących lub krótkotrwałych i niezaangażowanych relacji w związkach w dorosłym życiu (np. Bowlby, 1973; Hazan, Shaver, 1987). Hazan i Shaver wskazują, że jakość przywiązania dziecko-opiekun może wpływać na orientacje, które dorośli ostatecznie przyjmą wobec romantycznych partnerów. Osoby, które prezentowały unikający styl przywiązania do swoich głównych opiekunów jako dzieci (a więc te, które zazwyczaj unikały opiekuna, kiedy były przygnębione), preferują krótkoterminowe związki, które zazwyczaj nie charakteryzują się bliskością i zaangażowaniem w okresie dorosłości. Osoby o stylu przywiązania lękowo-ambiwalentnym (a więc te, które zazwyczaj potrzebowały bliskości opiekuna długo po zniknięciu przygnębienia) jako osoby dorosłe mogą preferować tworzenie zaangażowanych i długoterminowych relacji. Osoby o bezpiecznym stylu przywiązania (czyli te, które zazwyczaj szukały kontaktu z opiekunem, kiedy były przygnębione, ale po zniknięciu przygnębienia wracały do autonomicznej relacji) też mogą preferować długotrwałe i zaangażowane relacje, bez występowania obsesyjnej potrzeby bliskości i zaangażowania charakterystycznej dla osób o lękowo-ambiwalentnym stylu przywiązania. Ostatnie badania wykazały, że osoby nierestrykcyjne są bardziej skłonne do prezentowania unikającego stylu przywiązania (Simpson i Gangestad, 1989b). Mimo że te przypuszczenia i ustalenia są tylko spekulacjami, zasadne wydaje się stanowisko, że wczesne doświadczenia mogą mieć ogromny wpływ na rozwój i wyrażaną w dorosłości socjoseksualność (patrz także Draper, Harpending, 1982).

Poza czynnikami środowiskowymi, również czynniki genetyczne mogą odgrywać rolę w kształtowaniu się socjoseksualności. Gangestad, Simpson (1989; 1990) wskazali, że SOI koreluje umiarkowanie (.20 do .50) z kilkoma miarami osobowości w Kwestionariuszu Osobowości Wielowymiarowej Tellegena (1982) (ang. Multidimensional Personality Questionnaire), dawniej znanym jako Zróżnicowany Kwestionariusz Osobowości (ang. Differential Personality Questionnaire), z których każda wydaje się posiadać elementy dziedziczne (np. potencjał społeczny, unikanie szkody, agresja i absorpcja; Tellegen i in., 1988). Ostatnie badania przeprowadzone na bliźniętach wskazują, że znaczna liczba różnic, które socjoseksualność dzieli z w/w miarami, może mieć charakter genetyczny (Gangestad, Simpson, 1989; 1990). Badania na bliźniętach 
przeprowadzone przez Martina i Eysencka (1976), polegające na bezpośrednim zbadaniu zachowań seksualnych, wykazały, że różnica podkreślająca kilka niebezpośrednich wskaźników postaw socjoseksualnych (np. permisywizm, seks bezosobowy) ma swoje podłoże zarówno w genetyce, jak i środowisku. Jeżeli kolejne badania potwierdzą te ustalenia, przyszłe prace będą musiały uwzględniać genetyczne uposażenie i wpływ środowiska na kształtowanie się indywidualnych różnic w socjoseksualności.

\section{Jakie motywacje leżą u podstaw socjoseksualności?}

Ludzie mogą być skłonni do podejmowania niezobowiązujących relacji seksualnych z różnych powodów. Wyniki z badań 5 i 6 wskazują, że indywidualne różnice w ogólnym poziomie popędu płciowego, satysfakcji seksualnej, poczucia winy seksualnej oraz lęku związanego ze współżyciem nie wydają się głównym źródłem różnic indywidualnych w socjoseksualności. Mając na uwadze te ustalenia, trzeba zastanowić się nad tym, jakie rodzaje motywacji mogą tworzyć indywidualne różnice w skłonności do podejmowania niezobowiązujących relacji seksualnych.

Niektóre osoby mogą być nierestrykcyjne, ponieważ czerpią radość z seksu z różnymi partnerami. Chociaż pragnienie różnorodności seksualnej jest bardziej rozpowszechnione wśród mężczyzn niż wśród kobiet (Buss, 1985; DeLamater, 1987; Symons, 1979), niektóre kobiety najwyraźniej także podejmują niezobowiązujące relacje seksualne dla zaspokojenia potrzeby seksualnej różnorodności (Kinsey i in., 1953). Inne osoby mogą mieć orientację nierestrykcyjną, ponieważ nie chcą albo nie potrafią stworzyć psychicznej i emocjonalnej bliskości z partnerem. Idąc tym tropem, warto zwrócić uwagę, że dwie cechy główne socjopatii (osobowości antyspołecznej) to swoboda seksualna i niemożność nawiązania bliskiej więzi emocjonalnej z innymi (Robins, 1966). Chociaż większość osób o orientacji nierestrykcyjnej prawdopodobnie nie posiada prawdziwie socjopatycznych skłonności, niewielki podzbiór tych osób może jednak przejawiać subkliniczne (utajone) formy tego zaburzenia. Jeszcze inne osoby (zwłaszcza kobiety, z uwzględnieniem obecnego kontekstu kulturowego) mogą być gotowe do podjęcia niezobowiązujących relacji seksualnych głównie dla utrzymania przy sobie pożądanych partnerów, mimo że w rzeczywistości pragną długotrwałych i zaangażowanych relacji (Gangestad, Simpson, 1990). Najnowsze badania nad socjoseksualnością wykazały, że nierestrykcyjne kobiety w stosunku do restrykcyjnych przejawiają tendencje do randek z bardziej atrakcyjnymi mężczyznami (Simpson, Gangestad, 1989) i doświadczają zwykle 
silniejszego cierpienia emocjonalnego po rozpadzie związku (Simpson, 1987). Są to trzy potencjalne źródła motywacji, które mogą leżeć u podstaw zachowań wyrażających socjoseksualność.

\section{Jak poziom socjoseksualności wpływa na zapoczątkowanie i utrzymanie związku?}

Różnice indywidualne w socjoseksualności mogą mieć znaczący wpływ na zrozumienie inicjowania i utrzymania relacji. Na przykład, biorąc pod uwagę, że osoby restrykcyjne zazwyczaj tworzą długotrwałe i zaangażowane związki, a osoby nierestrykcyjne związki krótkotrwałe i niezaangażowane, uzasadnione zdaje się założenie, że te dwie grupy kierują się różnymi kryteriami przy rozpoczynaniu romantycznych relacji. Osoby restrykcyjne mogą być bardziej skłonne do wyboru partnerów na podstawie atrybutów, które zwykle sprzyjają zaangażowanej i stabilnej relacji (np. wierność partnera, zgodność charakterów, zdolność do wyrażania emocji), natomiast osoby nierestrykcyjne mogą kierować się kryteriami, które niekoniecznie prowadzą do powstania zaangażowanych i stabilnych relacji (np. atrakcyjność fizyczna, charyzma). Ostatnie badania nad parami będącymi na etapie spotykania się potwierdzają te przypuszczenia (Simpson, Gangestad, 1989c).

Przyszłe badania powinny określić, czy te same kryteria różnie wpływają na satysfakcję z relacji oraz powody rozpadu związku. Na przykład, czy osoby nierestrykcyjne są bardziej zadowolone, gdy podejmują relacje $\mathrm{z}$ atrakcyjnymi i charyzmatycznymi partnerami? Czy satysfakcja ze związku dla osób restrykcyjnych uzależniona jest od wyrażanych przez partnera emocji i jego wierności? Czy relacje tworzone przez osoby nierestrykcyjne są częściej narażone na rozpad w sytuacji nagłego obniżenia atrakcyjności oraz charyzmy partnera? Czy osoby restrykcyjne są bardziej podatne na zakończenie związku w sytuacji, kiedy ich partner nie jest w stanie lub nie chce zapewnić im wierności, harmonii czy silnego uczucia? Ponadto, czy i jaki wpływ na związek małżeński lub jego odpowiednik mają te przeciwstawne orientacje?

W ciągu ostatnich dziesięciu lat pojawiły się dwa ważne trendy w obszarze relacji międzyludzkich. Po pierwsze, zaczęto uwzględniać ogromny wpływ różnic $\mathrm{w}$ orientacji na tworzenie, utrzymanie i rozpad romantycznych związków (Clark, Reis, 1988). Po drugie, zaczęto uznawać rolę, jaką seks i seksualność odgrywają w przebiegu i końcowym charakterze romantycznych związków (Rubin,1984). Nasze badania nad socjoseksualnością łączą ze sobą oba trendy. W ten sposób przedstawiają one pierwszą zewnętrznie potwierdzoną 
miarę zaprojektowaną tak, aby określała socjoseksualne postawy i zachowania. Miara ta pozwoli na lepsze zrozumienie tego, jak zmienność socjoseksualności istniejąca w obrębie płci wpływa na interakcje między wyżej wymienionymi aspektami.

\section{Bibliografia}

Alston, L. R., Tucker, E. (1973). The Myth of Sexual Permissiveness. Journal of Sex Research, 9, 34-40.

Berscheid, E. (1983). Emotion. w: H. H. Kelley, E. Berscheid, A. Christensen, J. H. Harvey, T. L. Huston, G. Levinger, E. McClintock, L. A. Peplau, D. R. Peterson (red.), Close Relationships (s. 110-168). San Francisco: Freeman.

Berscheid, E., Walster, E. H. (1978). Interpersonal Attraction (2nd ed.). Reading, MA: Addison-Wesley.

Bowlby, J. (1973). Attachment and Loss: Vol. 2. Separation: Anxiety and Anger. New York: Basic Books.

Buss, D. M. (1985). Human Mate Selection. American Scientist, 73, 47-51.

Buss, D. M., Barnes, M. (1986). Preferences in Human Mate Selection. Journal of Personality and Social Psychology, 50, 559-570.

Byrne, D. (1983). The Antecedents, Correlates, and Consequents of Erotophobia- Erotophilia. w: C. M. Davis (red.), Challenges in Sexual Science (53-75). Philadelphia: Society for the Scientific Study of Sex.

Byrne, D., Sheffield, J. (1965). Response to Sexually Arousing Stimuli as a Function of Repressing and Sensitizing Defenses. Journal of Abnormal Psychology, 70, 114-118.

Cattell, R. B. (1966). The Scree Test for the Number of Factors. Multivariate Behavioral Research, 1, 245-276.

Clark, M. S., Reis, H. T. (1988). Interpersonal Processes in Close Relationships. Annual Review of Psychology, 39, 609-672.

Clayton, R. R., Bokemeier, J. L. (1980). Premarital Sex in the Seventies. Journal of Marriage and the Family, 42, 34-50.

Cohen, J., Cohen, E. (1983). Applied Multiple Regression/Correlation Analysis for the Behavioral Sciences. Hillsdale, NJ: Erlbaum.

Cronbach, L. J. (1990). Essentials of Psychological Testing (5th ed.). New York: Harper \& Row. 
Jeffry A. Simpson, Steven W. Gangestad, Emilia Aksamit Indywidualne różnice...

Cronbach, L. J., Meehl, P. E. (1955). Construct Validation in Psychological Tests. Psychological Bulletin, 52, 281-302.

Curran, J. P., Neff, S., Lippold, S. (1973). Correlates of Sexual Experience Among University Students. Journal of Sex Research, 9, 124-131.

D’Augelli, J. E., Cross, H. J. (1975). Relationship of Sex Guilt and Moral Reasoning to Premarital Sex in College Women and in Couples. Journal of Consulting and Clinical Psychology, 13, 40-47.

D’Augelli, J. E, D’Augelli, A. R. (1977). Moral Reasoning and Premarital Sexual Behavior: Toward Reasoning about Relationships. Journal of Social Issues, 33, 46-66.

Davis, C. M., Yarber, W. L., Davis, S. L. (red.). (1988). Sexuality-Related Measures: A Compendium. Lake Mills, IA: Graphic.

DeLamater, J. (1987). Gender Differences in Sexual Scenarios. w: K. Kelley (red.), Females, Males, and Sexuality (s. 127-139). Albany, NY: SUNY Press.

Draper, E., Harpending, H. (1982). Father Absence and Reproductive Strategy: An Evolutionary Perspective. Journal of Anthropological Research, 38, 235-243.

Ehrmann, W. (1959). Premarital Dating Behavior. New York: Holt, Rinehart \& Winston.

Eysenck, H. J. (1974). Personality, Premarital Sexual Permissiveness, and Assortative Mating. Journal of Sex Research, 10, 47-51.

Eysenck, H. J. (1976). Sex and Personality, London: Open Books.

Fei, J., Berscheid, E. (1977). Perceived Dependency, Insecurity, and Love in Heterosexual Relationships: The Eternal Triangle. Unpublished Manuscript, University of Minnesota.

Fisher, W. A. (1984). Predicting Contraceptive Behavior Among University Men: The Roles of Emotions and Behavioral Intentions. Journal of Applied Social Psychology, 14, $104-123$.

Gangestad, S. W., Simpson, J. A. (1989). On Human Sociosexual Variation: An Evolutionary Model of Mating Propensities. Unpublished Manuscript, University of New Mexico.

Gangestad, S. W., Simpson, J. A. (1990). Toward an Evolutionary History of Female Sociosexual Variation. Journal of Personality, 58, 69-96.

Gerrard, M. (1980). Sex Guilt and Attitudes Toward Sex in Sexually Active and Inactive Female College Students. Journal of Personality Assessment, 44, 258-261.

Gerrard, M., Gibbons, E X. (1982). Sexual Experience, Sex Guilt, and Sexual Moral Reasoning. Journal of Personality, 50, 345-359. 
Griffit, W. (1973). Response to Erotica and the Projection of Response to Erotica in Opposite Sex. Journal of Experimental Research in Personality, 6, 330-338.

Griffit, W., Hatfield, E. 0985). Human Sexual Behavior. Glenview, IL: Scott \& Foresman.

Hazan, C., Shaver, P. (1987). Romantic Love Conceptualized as an Attachment Process. Journal of Personality and Social Psychology, 52, 502-511.

Hendrick, S., Hendrick, C., Slapion-Foote, M. J., Foote, E. H. (1985). Gender Differences in Sexual Attitudes. Journal of Personality and Social Psychology, 48, 1630-1642.

Hunt, M. (1974). Sexual Behavior in the 1970s. Chicago: Playboy Press.

Jessor, R., Costa, E., Jessor, L., Donovan, J. E. (1983). Time of First Intercourse: A Prospective Study. Journal of Personality and Social Psychology, 44, 608-626.

Jurich, A. P., Jurich, J. A. (1974). The Effect of Cognitive Moral Development Upon the Selection of Premarital Sexual Standards. Journal of Marriage and the Family, 36, 736-741.

Kelley, H. H. (1983). Love and Commitment. In H. H. Kelley, E. Berscheid, A. Christensen, J. H. Harvey, T. L. Huston, G. Levinger, E. McClintock, L. A. Peplau, D. R. Peterson (red.), Close Relationships (s. 265-314). San Francisco: Freeman.

Kelley, H. H., Thibaut, J. W. (1978). Interpersonal Relations: A Theory of Interdependence. New York: Wiley.

Kelley, J. (1978). Sexual Permissiveness: Evidence for a Theory. Journal of Marriage and the Family, 40, 455-468.

Kinsey, A., Pomeroy, W., Martin, C. (1948). Sexual Behavior in the Human Male. Philadelphia: Saunders.

Kinsey, A., Pomeroy, W., Martin, C., Gebhard, E. (1953). Sexual Behavior in the Human Female. Philadelphia Saunders.

Landis, J. T., Landis, M. G. (1958). Building a Successful Marriage (3rd ed.). Englewood Cliffs, NJ: Prentice-Hall.

Leary, M. R., Dobbins, S. E. (1983). Social Anxiety, Sexual Behavior, and Contraceptive Use. Journal of Personality and Social Psychology, 45, 1347-1354.

Libby, R. W., Gray, L., White, M. (1978). A Test and Reformulation of Reference Group and Role Correlates of Premarital Sexual Permissiveness Theory. Journal of Marriage and the Family, 40, 79-92.

Loevinger, J. (1957). Objective Tests as Instruments of Psychological Theory. Psychological Reports, 3, 635-694. 
Lund, M. (1985). The Development of Investment and Commitment Scales for Predicting Continuity of Personal Relationships. Journal of Social and Personal Relationships, 2, 3-23.

Martin, N. G., Eysenck, H. J. (1976). Genetic Factors in Sexual Behaviour. w: H. Eysenck (red.), Sex and Personality (s. 192-219). London: Open Books.

Mellen, S. L. W. (1981). The Evolution of Love. Oxford, England: Freeman.

Mahoney, E. R. (1980). Religiosity and Sexual Behavior Among Heterosexual College Students. Journal of Sex Research, 16, 97-113.

Mosher, D. L. (1979). Sex Guilt and Sex Myths in College Men and Women. Journal of Sex Research, 15, 224-234.

Newcomb, M. D., Bentler, E M. (1981). Marital Breakdown. In S. Duck, R. Gilmour (red.), Personal Relationships 3: Personal relationships in Disorder (57-94). London: Academic Press. O’Grady, K. E., Janda, L. H., Gillen, H. B. (1979). A Multidimensional Scaling Analysis of Sex Guilt. Multivariate Behavioral Research, 14, 415-434.

Peplau, L. A., Rubin, Z., Hill, C. T. (1977). Sexual Intimacy in Dating Relationships. Journal of Social Issues, 33, 86-109.

Reiss, I. L. (1967). The Social Context of Premarital Sexual Permissiveness. New York: Holt, Rinehart \& Winston.

Reiss, I. L. (1982). Trouble in Paradise: The Current Status of Sexual Science. Journal of Sex Research, 18, 97-113.

Robins, L. R. (1966). Deviant Children Grown Up. A Sociological and Psychiatric Study of Sociopathic Personality, Baltimore: Williams \& Wilkins.

Rubin, Z. (1970). Measurement of Romantic Love. Journal of Personality and Social Psychology, 16, 265-273.

Rubin, Z. (1984). Toward a Science of Relationships. Contemporary Psychology, 29, 856-858.

Rusbult, C. E. (1980). Commitment and Satisfaction in Romantic Associations: A Test of the Investment Model. Journal of Experimental Social Psychology, 16, 172-186.

Simpson, J. A. (1987). The Dissolution of Romantic Relationships: Factors Involved in Relationship Stability and Emotional Distress. Journal of Personality and Social Psychology, 53, 683-692.

Simpson, J. A., Gangestad, S. W. (1989a). Two Month Test-Retest Reliability of the Sociosexual Orientation Inventory. Unpublished Data, Texas A\&M University.

Simpson, J. A., Gangestad, S. W. (1989b). Sociosexuality and Patterns of Attachment. Unpublished Data, Texas A\&M University. 
Simpson, J. A., Gangestad, S. W. (1989c). Sociosexuality and Romantic Partner Choice. Unpublished Manuscript, Texas A\&M University.

Snyder, M., Simpson, J. A., Gangestad, S. (1986). Personality and Sexual Relations. Journal of Personality and Social Psychology, 51, 181-190.

Symons, D. (1979). The Evolution of Human Sexuality, New York: Oxford University Press.

Tellegen, A. (1982). A Short Manual for the Differential Personality Questionnaire.Unpublished Manuscript, University of Minnesota.

Tellegen, A., Lykken, D. T., Bouehard Jr., T. J., Wilcox, K. J., Segal, N. L., Rich, S. (1988). Personality Similarity in Twins Reared Apart and Together. Journal of Personality and Social Psychology, 54, 1031-1039.

Wicker, A. W (1969). Attitudes Versus Action: The Relationship of Verbal and Overt Behavioral Responses to Attitude Objects. Journal of Social lssues, 25, 41-78.

Zuckerman, M., Bone, R. N., Near, R., Mangelsdorff, D., Brustman, B. (1972). What is the Sensation Seeker? Personality Trait and Experience Correlates of the Sensation Seeking Scales. Journal of Consulting and Clinical Psychology, 39, 308-321.

Zuckerman, M., Tushup, R., Finner, S. (1976). Sexual Attitudes and Experience: Attitude and Personality Correlates and Changes Produced by a Course in Sexuality. Journal of Consulting and Clinical Psychology, 44, 7-19.

\section{Załącznik A}

Biorąc pod uwagę nieco wyższą wewnętrzną spójność trzech pozycji dotyczących postaw w stosunku do całego Inwentarza Orientacji Socjoseksualnej (SOI), można się zastanawiać, dlaczego nie zbudować inwentarza socjoseksualności bazującego wyłącznie na badaniu postaw. Nie zrobiliśmy tego z trzech powodów. Po pierwsze, chociaż wskaźniki postaw odzwierciedlają postawy socjoseksualne bardziej niż cały Inwentarz Orientacji Socjoseksualnej odzwierciedla całą zmienną (postawy plus zachowanie), wskaźnik ten nie ocenia w pełni sfery socjoseksualności, w przeciwieństwie do SOI. Po drugie, niektóre z elementów behawioralnych (np. liczba partnerów w ubiegłym roku), są silnie zależne od czynnika określającego gotowość do podejmowania niezobowiązujących relacji seksualnych, podobnie zresztą jak wskaźniki postaw. Po trzecie, staraliśmy się stworzyć inwentarz, którego pozycje byłyby zróżnicowane a przepustowość rozległa (patrz Cronbach, 1990).

Mimo że wewnętrzna spójność SOI jest wystarczająca, można zapytać, dlaczego nie wykorzystaliśmy większej liczby pozycji do jego stworzenia. 
Istnieje stosunkowo mało wyraźnych i unikalnych behawioralnych markerów socjoseksualności. Staraliśmy się zaproponować szeroki zakres najbardziej optymalnych wskaźników zachowania, równocześnie utrzymując równowagę pomiędzy komponentami behawioralnymi i poznawczymi.

Zanim wszystkie pięć komponentów SOI zostało zsumowanych, wartość jednostkowa każdego z nich została zmierzona poprzez przekształcenie go w wynik znormalizowany (Z-score), jednakowo dla wszystkich badań. Z-scores mogą być zastąpione zbiorem prostych wag, których wartości jednostkowe są następujące:

$\mathrm{SOI}=5 \mathrm{x}$ (liczba partnerów $\mathrm{w}$ minionym roku $)+1 \mathrm{x}$ (liczba przewidywanych partnerów) $+5 x$ (liczba partnerów na jedną noc) $+4 x$ (częstotliwość seksualnych fantazji) $+2 \mathrm{x}$ (stosunek do podejmowania niezobowiązujących relacji seksualnych).

W tej próbie indeks korelacji wyniósł .89, włączając wynik znormalizowany (Z-score) przed zsumowaniem. Wyniki uzyskane przez mężczyzn wyniosły od 10 do 216 , a przez kobiety od 10 do 172 . Średni wynik mężczyzn to 68.51 , a kobiet 38. 90. Odchylenia standardowe wyniosły odpowiednio: 38.01 i 26.90.

\section{Załącznik B}

\section{Inwentarz Orientacji Socjoseksualnej (SOI)}

Proszę udzielić szczerych odpowiedzi na wszystkie poniższe pytania. Odpowiedzi dotyczących zachowań udzielaj pisemnie w wyznaczonych miejscach. W pytaniach dotyczących postaw i myśli, zakreśl na skali liczbę, która najlepiej odpowiada Twoim odczuciom.

1. Z iloma różnymi partnerami uprawiałeś seks w ciągu ostatniego roku?

2. Z iloma różnymi partnerami przewidujesz uprawiać seks w ciągu najbliższych pięciu lat? (Proszę podać konkretna, realistyczna liczbę)

3. Z iloma różnymi partnerami uprawiałeś seks tylko $i$ wytacznie raz?

4. Jak często fantazjujesz o seksie z kimś innym niż z obecnym partnerem? (Zakreśl jedną odpowiedź).

1. nigdy

2. raz na dwa lub trzy miesiące

3. raz $\mathrm{w}$ miesiącu

4. raz na dwa tygodnie

5. raz w tygodniu 
6. kilka razy w tygodniu

7. prawie codziennie

8. co najmniej raz dziennie

5. Seks bez miłości jest OK.

\begin{tabular}{lllllllll}
1 & 2 & 3 & 4 & 5 & 6 & 7 & 8 & 9 \\
\hline Zdecydowanie się nie zgadzam & & & Zdecydowanie się zgadzam
\end{tabular}

Potrafię wyobrazić sobie, że czuję się komfortowo i jestem usatysfakcjonowany z niezobowiązującego seksu z różnymi partnerami.

\begin{tabular}{lrrrrrrrr}
1 & 2 & 3 & 4 & 5 & 6 & 7 & 8 & 9 \\
\hline Zdecydowanie się nie zgadzam & & & Zdecydowanie się zgadzam
\end{tabular}

Musiałbym czuć silne przywiązanie (emocjonalne i psychiczne), aby być zadowolonym i czuć się komfortowo w relacji seksualnej z partnerem. ${ }^{6}$

\begin{tabular}{lllllllll}
1 & 2 & 3 & 4 & 5 & 6 & 7 & 8 & 9 \\
\hline Zdecydowanie się nie zgadzam & & & Zdecydowanie się zgadzam
\end{tabular}

${ }^{6}$ Pozycja 7 powinna być odczytana odwrotnie przed dodaniem wyników z pytań $5-7$. Wyniki poszczególnych pozycji Inwentarza Orientacji Socjoseksualnej powinny zostać zsumowane według poniższego schematu: $\mathrm{SOI}=5 \mathrm{x}($ odp. na pyt. 1$)+1 \mathrm{x}$ (odp. na pyt. 2$)+5 \mathrm{x}$ (odp. na pyt. $3)+4 x$ (odp. na pyt. 4) $+2 x$ (suma pozycji 5-7). Aby ograniczyć nieproporcjonalnie duży wpływ na końcowy wynik testu, maksymalna wartość odpowiedzi na pytanie 2 powinna wynosić 30 partnerów. 